\title{
The Development of Gametophyte Sterilization Method for Liverworts Acrolejeunea fertilis (Reinw., Blume and Nees) Schiffn. In vitro Culture
}

\author{
Mouleidi Dwi Putri, Windri Handayani, Astari Dwiranti, Andi Salamah, Niarsi Merry Hemelda, Afiatry Putrika* \\ Department of Biology, Faculty of Mathematics and Natural Sciences, Universitas Indonesia, Depok, Indonesia
}

ARTICLE INFO

Article history:

Received June 1, 2020

Received in revised form December 3, 2020

Accepted December 10, 2020

\section{KEYWORDS}

Acrolejeunea fertilis,

contamination,

gametophyte,

In vitro,

sterilization

\begin{abstract}
In vitro culture gametophytes of leafy liverworts often have problems in their sterilization process. These problems due to the high level of contamination and the fragile structure of the gametophyte leafy liverworts. The structures can be easily to damage after exposure to disinfectant. This study aimed to observe the concentration and the exposure time of "Bayclin" commercial bleach to suppress contamination with the viability of Acrolejeunea fertilis gametophytic explants. This research was conducted using control and 6 combination treatments with "Bayclin" concentration $(1.00 \%, 1.25 \%$, and $1.50 \%)$ and exposure time 60 and 120 seconds, then accompanied by the addition of Tetracycline $2.5 \mathrm{mg} / \mathrm{ml}$. The qualitative parameters observed were the explant color, the type and location of contamination, and the growth of explants. The quantitative parameters were the percentage of contamination, the percentage of growth, and the number of new branches. The results showed that "Bayclin" $1.25 \%$ and $1.50 \%$ with 60 seconds exposure time has the lowest percentage of contamination which is $70 \%$ until the 7 th days after planting. The most common type of internal contamination from the explant is bacteria and fungi. However, the growth of the new branch still occurs in some explants even though it has been contaminated and browned.
\end{abstract}

\section{Introduction}

Acrolejeunea fertilis (Reinw., Blume and Nees) Schiffn. is one of the leafy liverworts species (Marchantiophyta). The species belongs to the largest family of liverworts, namely Lejeuneaceae (Wang et al. 2014). The potential of $A$. fertilis has not been much explored yet due to less favored research objects than higher plants (Sabovljevic et al. 2012). According to Gradstein et al. (1988), A. fertilis contains terpenoids and also potentially contains other bioactive compounds. Therefore, the pure culture of $A$. fertilis is needed for available research material with stable biomass (Krishnan and Murugan 2014).

In vitro culture is one of the alternative techniques for increasing plant biomass vegetatively in an axenic condition (George et al. 2008). The key step to determine the success of axenic conditions is the process of explant sterilization. This step aims to

\footnotetext{
* Corresponding Author

E-mail Address: a.putrika@sci.ui.ac.id
}

eliminate contaminants in the tissue (endophytes) and explant surfaces (Ayele and Tefera 2018). Some types of disinfectants commonly used for surface sterilization of explants are pure sodium hypochlorite $(\mathrm{NaOCl})$ (Adam 1996; Sabovljevic et al. 2009; Sabovljevic et al. 2012; Awasthi and Pande 2015; Beike et al. 2010) and commercial bleach (Sabovljevic et al. 2003; Vujicic et al. 2010). Both of the compounds contain $\mathrm{HOCl}$ which is able to provide antimicrobial activity effectively against vegetative cells and bacterial spores, fungi, algae, protozoa, and viruses (Duckett et al. 2004).

Explant sterilization methods include the type, concentration, and time of exposure of sterilant depending on the parts of the plant to be used (Firoz et al. 2016). The types of explants in leafy liverworts may be spores or gametophytes. Spores of leafy liverworts in vitro culture initiation has a higher success rate than gametophyte. This is because the spores are protected by the capsule that makes the spores in a sterile condition and is not directly exposed to sterilizer material (Krishnan and 
Murugan 2014). However, based on the life cycle of liverworts, the sporophyte phase is shorter than the gametophyte phase (Awasthi 2009). Therefore, the gametophyte will be ideal as an alternative explant in leafy liverworts in vitro culture.

The success rate of the in vitro culture of leafy gametophyte explants varies due to high levels of contamination. Anatomically, leafy liverworts have a simple gametophyte structure and consist of one layer of cells without cuticles (Sabovljevic et al. 2003). Those cause the leafy liverwort tissue can be easily damaged and die with too high concentration and disinfectant exposure time, although free from contamination (Sabovljevic et al. 2003; Vujicic et al. 2010; Awasthi and Pande 2015). Therefore, this study focuses on developing sterilization methods for Acrolejeunea fertilis gametophyte explants to increase the success rate of in vitro culture using gametophyte explants.

\section{Materials and Methods}

\subsection{Location and Time}

The study was conducted at the Physiology Laboratory 2, Department of Biology, Faculty of Mathematics and Natural Sciences (FMIPA), Universitas Indonesia (UI). The samples for explant were taken from Terminalia catappa tree bark substrate at the FMIPA UI. The time period of research starts from February to June 2019.

\subsection{Explants Sterilization}

The sterilization method consists of a control and 6 treatment combinations from "Bayclin" concentration (1.00\%,1.25\%, and $1.50 \%$ )and exposuretime(60and 120 seconds). First of all, explant washed using distillate running water for 5 minutes outside the Laminar Air Flow Cabinet (LAFC). Then the explants were brought into the LAFC to be sterilized gradually. The first step was washing Acrolejeunea fertilis explants with 10 $\mathrm{ml}$ of sterile aquades in a $15 \mathrm{ml}$ sterile tube for 3 minutes. The second step was exposing the explants to "Bayclin" disinfectants with the concentration and time of exposure depending on each treatment (Table 1 ). The third step was sterilizing the explant using $2.5 \mathrm{mg} / \mathrm{ml}$ Tetracycline antibiotic solution which was exposed for 60 seconds on the explants. Explants were washed 3 times with $10 \mathrm{ml}$ of sterile aquades each time the sterilant was exposed. Furthermore, the explants were planted in medium containing agar
Table 1. Sterilization treatment code for gametophyte Acrolejeunea fertilis explant

\begin{tabular}{|c|c|}
\hline $\begin{array}{l}\text { Treatment } \\
\text { code }\end{array}$ & Sterilant \\
\hline K1 & Tetracycline $2.5 \mathrm{mg} / \mathrm{ml}$ (60 second) \\
\hline AY1 & $\begin{array}{l}\text { "Bayclin" } 1.00 \% \text { (60 second) + Tetrasiklin } 2.5 \\
\mathrm{mg} / \mathrm{ml} \text { (60 second) }\end{array}$ \\
\hline AZ1 & $\begin{array}{l}\text { "Bayclin" } 1.00 \% \text { (120 seconds) + Tetrasiklin } \\
2.5 \mathrm{mg} / \mathrm{ml} \text { (60 second) }\end{array}$ \\
\hline BY1 & $\begin{array}{l}\text { "Bayclin" } 1.25 \% \text { (60 second) }+ \text { Tetrasiklin } 2.5 \\
\mathrm{mg} / \mathrm{ml}(60 \text { second })\end{array}$ \\
\hline BZ1 & $\begin{array}{l}\text { "Bayclin" } 1.25 \% \text { (120 seconds) + Tetrasiklin } \\
2.5 \mathrm{mg} / \mathrm{ml} \text { (60 second) }\end{array}$ \\
\hline CY1 & $\begin{array}{l}\text { "Bayclin" } 1.50 \% \text { (60 second) + Tetrasiklin } 2.5 \\
\mathrm{mg} / \mathrm{ml} \text { (60 second) }\end{array}$ \\
\hline CZ1 & $\begin{array}{l}\text { "Bayclin" 1.50\% (120 seconds) + Tetrasiklin } \\
2.5 \mathrm{mg} / \mathrm{ml} \text { (60 second) }\end{array}$ \\
\hline
\end{tabular}

( $7 \mathrm{gr} / \mathrm{l}$ ) with $1 / 2 \mathrm{MS}$ composition. The whole group was done twice repeatedly with 5 bottles of culture for each repetition. The total sample consists of 10 bottles, each bottle containing 3 explants.

\subsection{Culture Environment and Observation}

The culture bottles were kept in the growth chamber at $23 \pm 2^{\circ} \mathrm{C}$ with humidity in the range of $38 \pm 2 \%$. The light sources were supplied by two coolwhite fluorescent tubes 18 watt with the photoperiod set to $16 \mathrm{~h}$ light and $8 \mathrm{~h}$ dark. The cultures were checked regularly for qualitative and quantitative parameters. Qualitative parameters include explant color, location and type of contamination, and the additional growth. The explants color categorized using the [Ace Paint] color standard. The location of contamination in culture bottles was grouped into two, which arise from explants (internal) and outside of explants (external). The types of contamination were compared with the literature. Quantitative parameters include the percentage of contamination, the percentage of growth, and the number of new branches. Observation of the percentage of contamination, as well as the location and type of contamination, was carried out at $0,3,7$, and 14 days, while branch growth was carried out until 30 days. Microscopic observation was carried out using a light microscope [Leica M500] and DinoLite [AM4115ZT].

\section{Results}

\subsection{Explant Color}

The typical explant color observed after sterilization (D0) and thirtieth days after planting 
(D30). The result of the entire sterilization method group can be seen in Table 2. Explant color can indicate the level of pigment contained in explant cells.

The increase of "Bayclin" concentration to the gametophyte of leafy liverworts explants are changed to yellowish after sterilization (D0) and become brownish to whitish after thirty days (D30). Meanwhile, the control group has the same color as the explants on the D0 and could not be observe until D30 because the contamination already covered whole surface of the explants.

\subsection{Explant Contamination}

\subsubsection{Percentage of Contamination}

The percentage of contamination results in all groups of sterilization methods can be seen in Figure 1. The control had been contaminated since the third days after planting (D3). The percentage of contamination is $60 \%$, while another treatment has not been contaminated. This showed that exposure to "Bayclin" $1.00--1.50 \%$ as a disinfectant in explants can suppress the growth of contaminants up to three days after planting.

However, the axenic condition cannot be maintained until the seventh days after planting (D7) and all of the culture bottles have been contaminated on the fourteenth days after planting (D14). All treatment groups experienced contamination on the D7 with a percentage above $50 \%$. The treatment of "Bayclin" 1.25--1.50\% with 60 seconds of exposure time had the lowest percentage of contamination (70\%) among other treatments on the D7.

\subsubsection{Location and Type of Contamination}

The location of contamination found in the culture bottle comes from external (Figure $2 a$ ) and internal (Figure 2b) or both. In general, the percentage of internal contamination was higher than the external, with an average percentage of more than $20 \%$. Internal

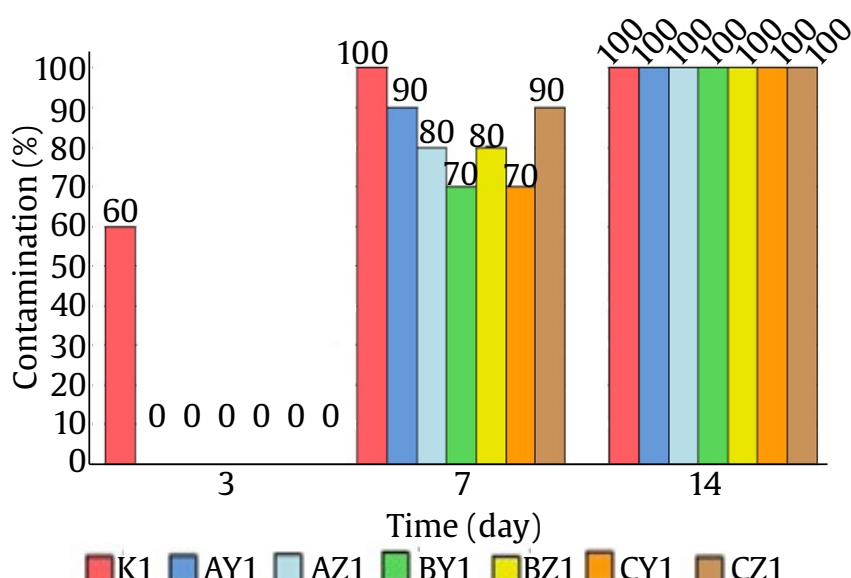

Figure 1. The percentage of contamination from each sterilization treatment on gametophyte Acrolejeunea fertilis culture after fourteenth days $(\mathrm{n}=10)$. $\mathrm{K} 1$ = Tetracycline $2.5 \mathrm{mg} / \mathrm{ml}(60$ second). AY1 = "Bayclin" 1.00\% (60 second) + Tetrasiklin $2.5 \mathrm{mg} / \mathrm{ml}$ (60 second). AZ1 = "Bayclin" $1.00 \%$ (120 seconds) + Tetrasiklin 2.5 $\mathrm{mg} / \mathrm{ml}$ (60 second). BY1 = "Bayclin" 1.25\% (60 second ) + Tetrasiklin $2.5 \mathrm{mg} / \mathrm{ml}$ (60 second). BZ1 = "Bayclin" 1.25\% (120 seconds) + Tetrasiklin 2.5 $\mathrm{mg} / \mathrm{ml}$ (60 second). CY1 = "Bayclin" 1.50\% (60 second) + Tetrasiklin $2.5 \mathrm{mg} / \mathrm{ml}$ (60 second). CZ1 $=$ "Bayclin" $1.50 \%$ (120 seconds) + Tetrasiklin 2.5 $\mathrm{mg} / \mathrm{ml}$ (60 second)

Table 2. The average color of gametophyte Acrolejeunea fertilis explant at the beginning of planting (D0) and the last days of observation (D30)

\begin{tabular}{llll}
\hline \multirow{2}{*}{ Before sterilization } & Treatment code & Day-0 (D0) & Day-30 (D30) \\
\cline { 3 - 4 } & & Spring hill & not observed
\end{tabular}

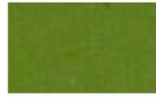

AZ1

Spring hill
AY1

BY1 -- BZ1

Springside

Summerside
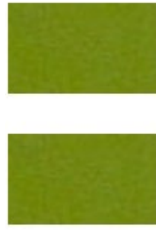

CY1 -- CZ1

Summerside

Lotus queen

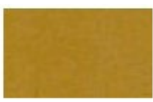

Pieces of eight

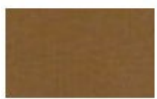

Autumn gold

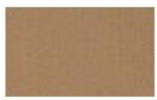

Butterscotch candy

Custard cream 
contamination occurred in all treatments including control. Identification of contaminants based on morphological characteristics, both macroscopically and microscopically.

The internal contamination in all groups generally caused by fungi, with an average percentage of more than $40 \%$. The result showed that the addition of "Bayclin" (5.25\% $\mathrm{NaOCl})$ for sterilization is not effective in inhibiting the growth of fungal contaminants on the surface or in tissue explants (endophytes). The variants of fungal contaminants can be seen in Figure 3 and 4. Based on macroscopic observation, the colony of some fungi have threadslike hyphae called mycelia (Figure 3 ). Microscopic observations are only made on the type of fungus whose vegetative body is not visible but only colored spots. Fungal contamination in the form of freckles or powdery textures found until the fourteenth days after planting consists of 4 colors, when viewed macroscopically. The four colors are yellow, black,

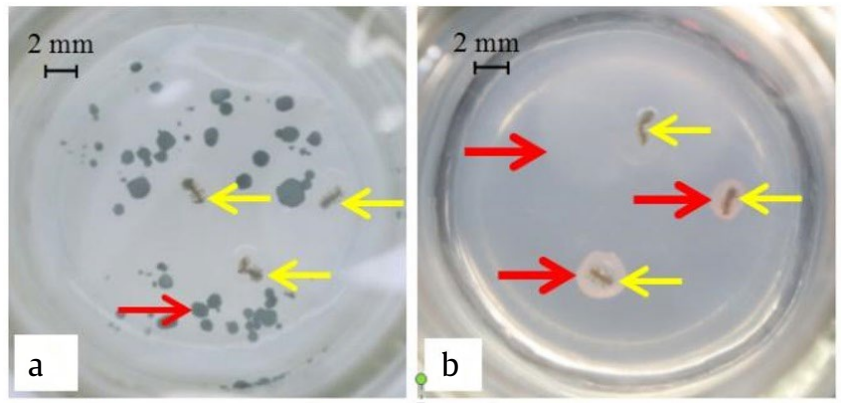

Figure 2. The position of contamination on gametophyte explant of Acrolejeunea fertilis explants in culture bottle. (a) External contamination (red arrow) outside the explant (yellow arrow). (b) Internal contamination (red arrow) on explant (yellow arrow) bluish green, and greenish black, which suspected to be spores of a fungus. The results of macroscopic and microscopic observations of colored spots can be seen in Figure 4.

The other type of contaminants which also found in research were bacteria and algae. Macroscopically, the bacterial contaminants found has a slippery texture such as mucus. Two bacterial colors were found in this work, namely white (Figure 5a) and pink (Figure 5b) at the first observation time. However, some white bacteria can be turned in to pink color in the following macroscopic observation. The microscopic structure of that bacteria can be seen in Figure 5c. Meanwhile, the algae contamination generally appears after the explants has been contaminated by bacteria and fungi $\left(21^{\text {st }}\right.$ days after planting). This showed that the growth rate of algae is slower than bacteria and fungi in the culture medium. Macroscopically and microscopically, the color of algae in this work is green and has a smooth texture (Figure 6).

\subsection{Explant Growth}

The additional shoot can indicate the viability of Acrolejeunea fertilis gametophyte explants. The browning and the presence of internal contamination on the explant did not always inhibit the possibility of shoot growth. Almost all explants that growth had experienced browning and contamination. Macroscopically and microscopically, the shoot growth in the $A$. fertilis gametophyte explants was seen emerging from the lateral side of the trunk, out of the armpit lobe, perpendicular direction to the stem, and the base that forms the collar structure (Figure 7).
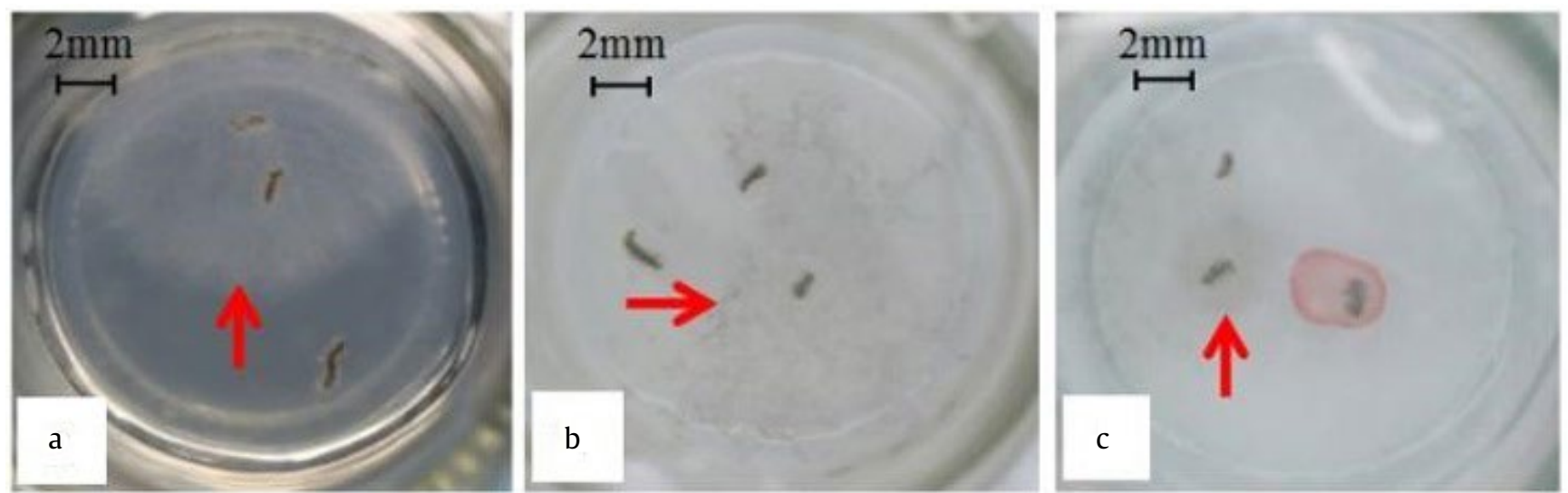

Figure 3. The variation of fungi mycelia contamination with (a) white, (b) black, and (c) chocolate color on gametophyte Acrolejeunea fertilis culture 
Color of spores

Yellow

Black

Black-green

Blacklish-green
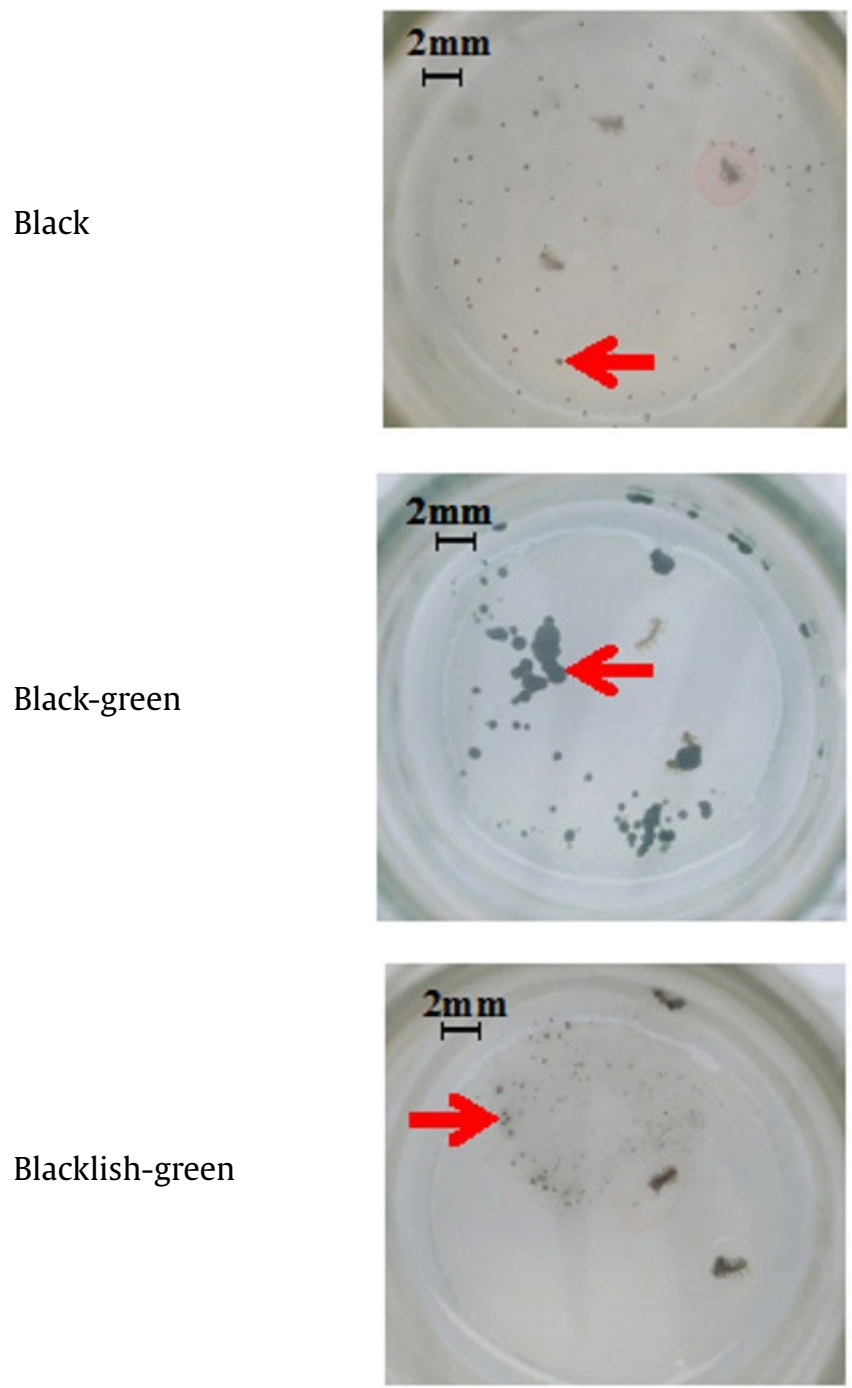

Microscopic
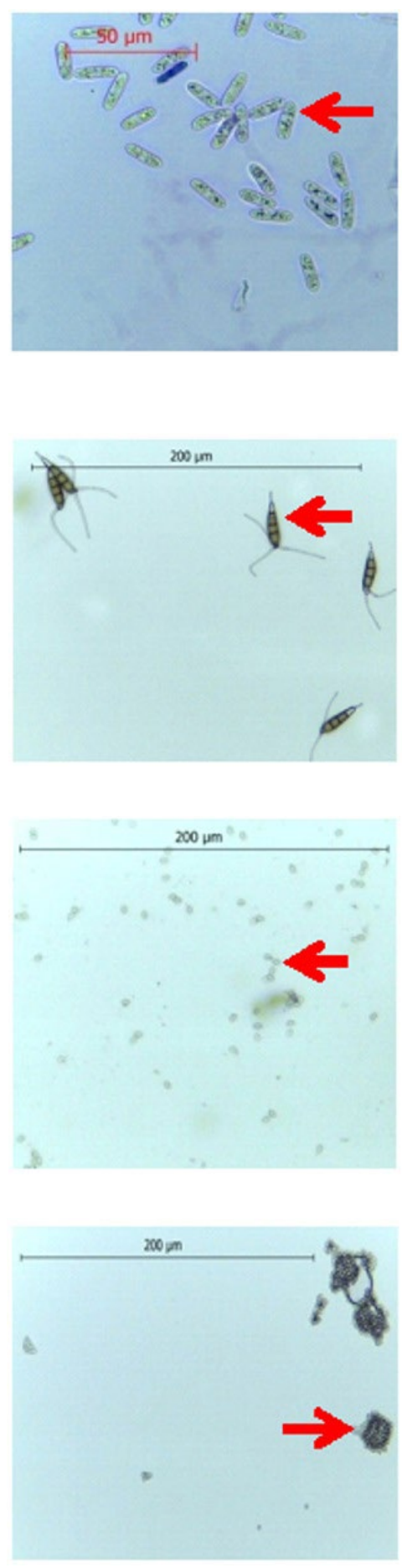

Figure 4. The types of fungal spores contamination based on macroscopic and microscopic observation 

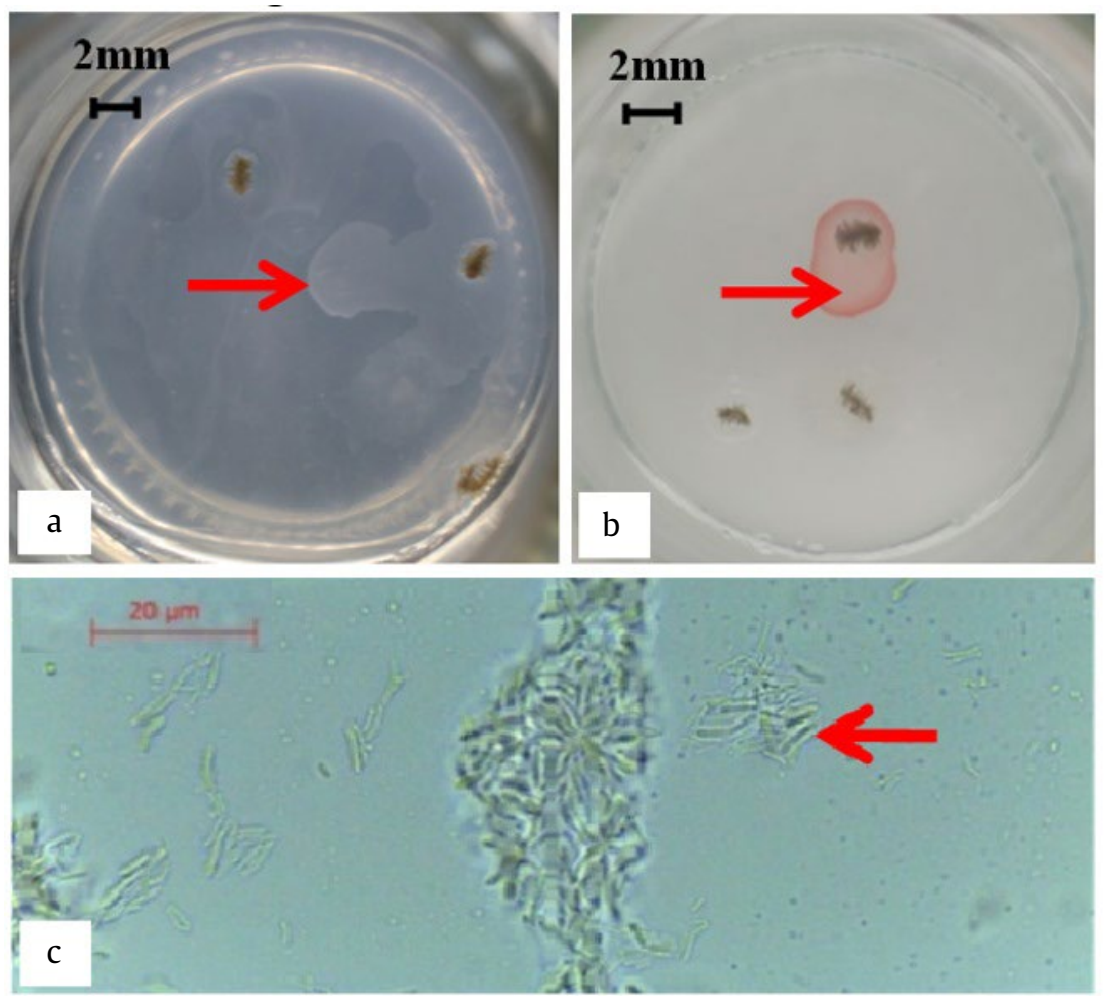

Figure 5. Bacterial contamination on gametophyte Acrolejeunea fertilis explants culture. (a) macroscopic white color bacteria, (b) macroscopic pink color bacteria, (c) microscopic bacteria

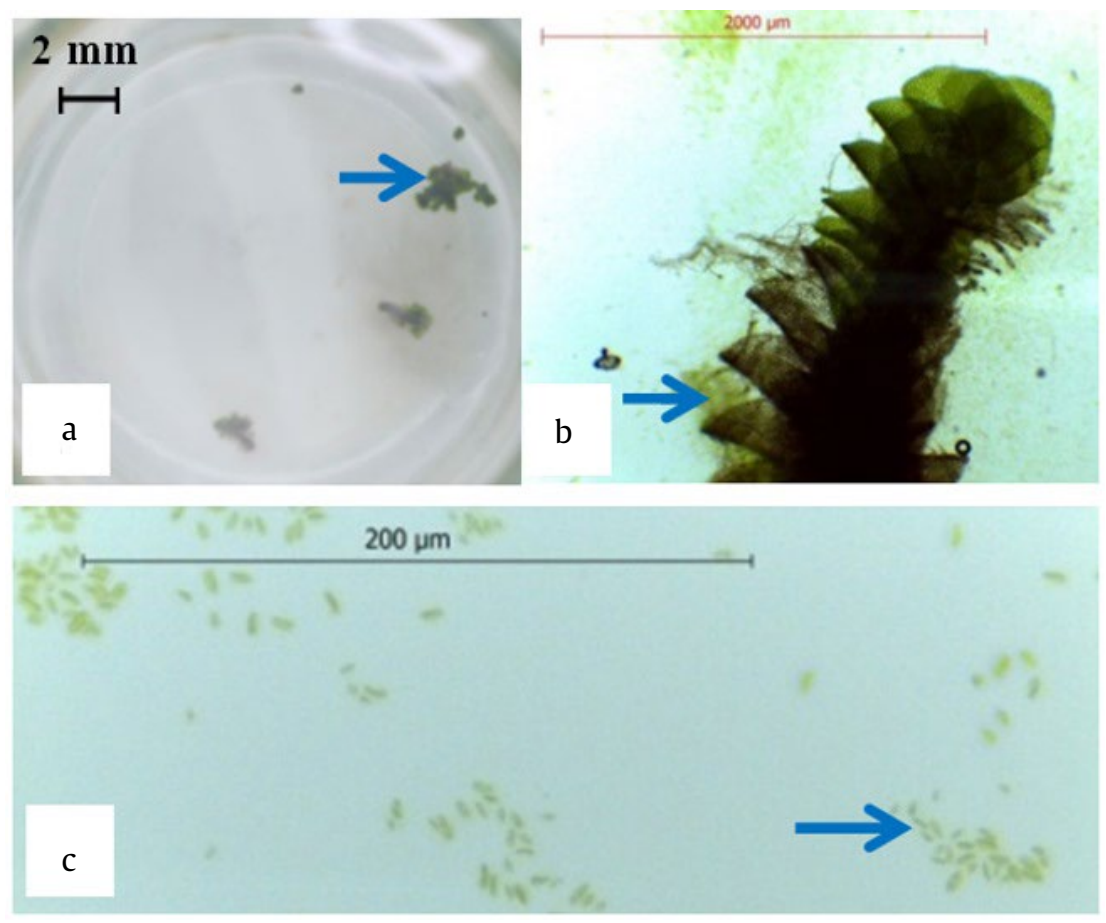

Figure 6. Algae contamination on gametophyte Acrolejeunea fertilis explants culture. (a) macroscopic branches growth in explants undergoing algae contamination, (b) microscopic explants growing with algae contamination, (c) microscopic alga 
The shoot growth already occured on the seventh days after planting (D7) in treatment with "Bayclin" $1.00 \%$ for 120 seconds and "Bayclin" $1.25--1.50 \%$ for 60 seconds of exposure (Table 3 ). The growth of the new branches in other treatment groups was only seen on the fouteenth days after planting (D14) because of the high internal contamination on the D7, so the shoot growth was inhibited. Meanwhile, the treatment of Bayclin $1.50 \%$ for 60 seconds of exposure has the highest percentage of explant growth (Table 3 ) with the highest number of new branches (16 branches).

\section{Discussion}

Natrium hypocloride $(\mathrm{NaOCl})$ content in "Bayclin" is known to induce oxidative reactions that cause degradation of fatty acids and amino acids (Estrela et al. 2002). Therefore, "Bayclin" with high concentration and time exposure longer, can cause the leafy liverworts gametophyte tissue damage easily due to the simple structure of the explant. The explant browning indicates the chlorophyll contents have been decreased, and the cells cannot convert
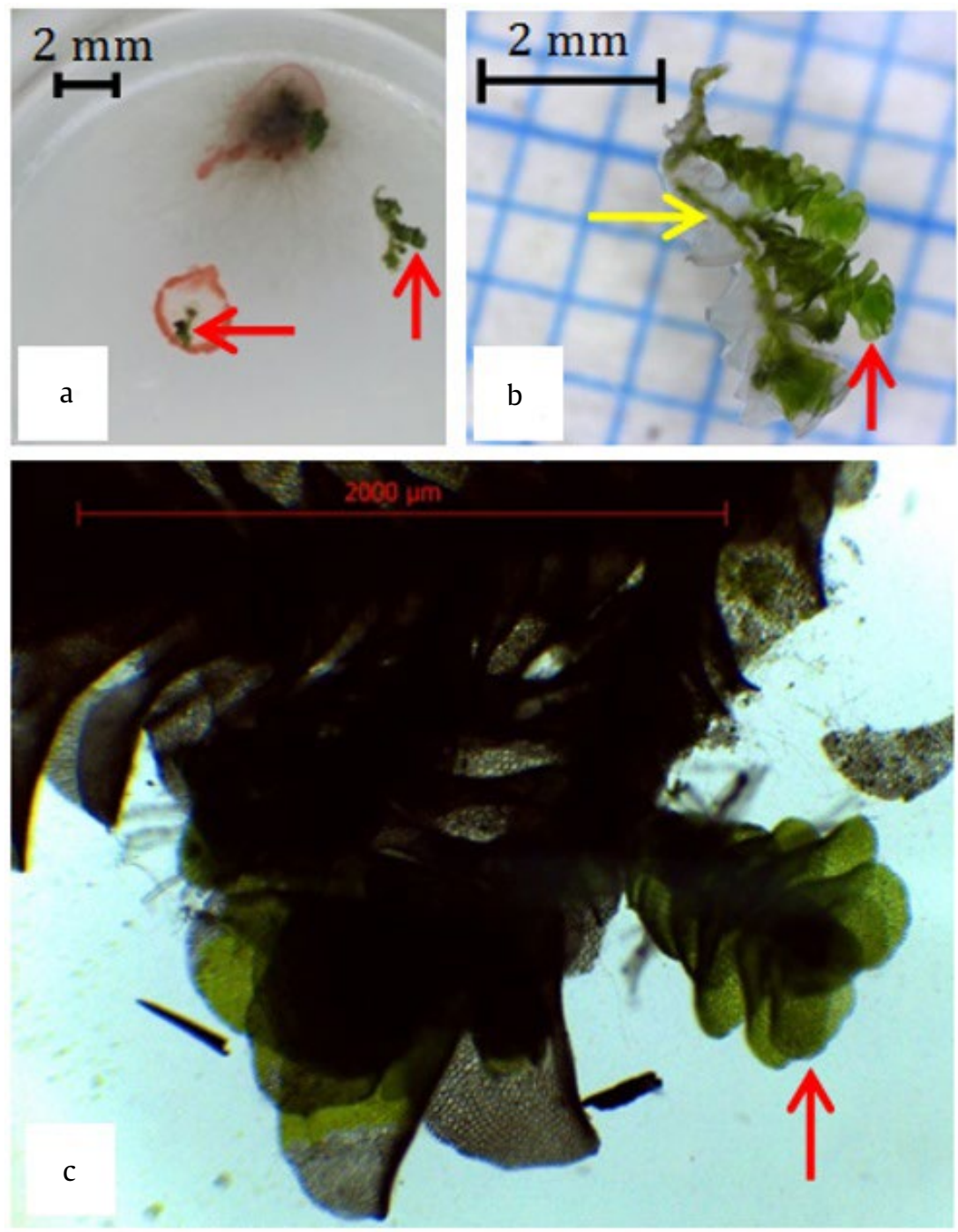

Figure 7. Branch growth on gametophyte Acrolejeunea fertilis explants. (a) Macroscopic branches growth on explants, (b) microscopic branches growth (red arrows) in the initial explants (yellow arrows) with dino-lite microscope, (c) microscopic branch growth axillary with a light microscope 
phenolic acids into flavonoids (Krishnan et al. 2014). The presence of atmospheric oxygen and polyphenol oxidase would oxidize phenols that accumulate in the tissue after the cell is damaged and caused browning in the tissues (Hua et al. 2008).

On the other hand, an increase in the "Bayclin" concentration in the observation can reduce the percentage of contamination. These results also occurred in the in vitro culture study of gametophyte moss by Awasthi and Pande (2015) and Vujicic et al. (2010). However, increasing the "Bayclin" exposure time in the study did not reduce the percentage of contamination. There might need a longer time of the cleaning process done when outside the LAFC. Besides that, washing the explants with sterile water thoroughly to clean the surface, and to stop the chemical reaction between the sterile solution with explants need to be longer (Mng'omba et al. 2012). Therefore, the increased concentration and time of "Bayclin" exposure must also be followed with the addition of time and repeated explant washing with sterile water to remove the excess of the "Bayclin" that can cause the explant to bleach.

The external contamination can be caused by the surrounding environment (Nadir 2018). Meanwhile, the internal contamination suspected to originate from explants due to sterilization methods that are not effective in eliminating spores and vegetative microorganisms on the explant surface. The results in the study showed the percentage of internal contamination was higher than the external, that's mean the main cause of contamination was ineffective sterilization methods.

According to Chopra and Kumra (1988), some mosses could not grow or even germinate without symbiosis with fungi and bacteria. Endophytic fungi are thought to have a positive correlation with liverworts in nature. Duckett et al. (2004) states that many liverworts had endophytic fungi alleged role in helping the host attachment to the substrate.

Kutschera and Koopman (2005), also found that there is an epiphytic pink bacteria, namely Methylobacteria on the surface of the gametophyte of the Marchantia and Lunularia liverworts. These bacteria are known to have positive effect on vegetative growth (gemmae) of liverworts and also occurred in the in vitro culture study of Stephensoniella brevipedunculata liverworts carried out by Awasthi and Pande (2015).

The internal fungal contamination was found higher than internal bacterial contamination in the study. According to Kritzinger et al. (1997), endophytic fungi in plants cannot be eliminated by only adding $\mathrm{NaOCl}$ for disinfection. Therefore, it is necessary to develop methods of sterilization, such as the addition of fungicides for the explant sterilization. The addition of type, concentration, or time exposure of antibiotic also needed in the study. The optimum concentration and time exposure of that bacteriostatic antibiotic can prevent the association of aminoacyl tRNA with the 30S ribosome, so that microbial protein synthesis is inhibited (Kumar and Singh 2009). Tetracycline antibiotics which used in the study are known to have a broad spectrum in killing vegetative bacterial cells (Chopra and Roberts 2001). However, the methods of used that antibiotic in the study still not effective enough to kill the internal bacterial contamination. Therefore, further research is needed related to the development of an effective sterilization method that kills fungi and bacteria in gametophyte explorer Acrolejeunea fertilis more effectively.

Even the contamination was occurred on the treatment group, the new branchs was still growth on explants culture. The branching characteristics of Acrolejeunea fertilis explants belongs to the Lejeunea type (Thiers 1982; Siregar et al. 2014). On the other hand, the shoot growth absence on the control group, allegedly occurred because the explants were contaminated by fungus with blue-green spores. The spores spread quickly and cover the surface of the explant and caused the explant to decay. According to Firoz et al. (2016), the presence of microorganisms in the in vitro culture can be increasing the explant mortality. Therefore, a lower level of contamination can increase the opportunity of explant to grow, so to increase the explant viability, an effective and optimize sterilization method still need to be developed.

\section{Conclusion}

The lowest percentage of contamination until the seventh days after planting occurred when $1.25 \%$ and $1.50 \%$ "Bayclin" was used for sterilization for 60 seconds. The type of contamination that often arises were internal contamination caused by fungus. Meanwhile, $1.00--1.50 \%$ concentration of "Bayclin" can cause the explants to turn yellow right after the sterilization process and becoming chocolate after 30 days. However, contamination and browning that occurs tend not to cause the viability of explant to disappear. The explants still can show some growth after exposure to the treatment during the sterilization process. Based on this method, we can improve the sterilization method from $A$. fertilis gametophyte and increasing the growth percentage with the appropriate chemicals and concentration. 


\section{Acknowledgements}

We wish to thank the Ministry of Research, Technology, and Higher Education of the Republic of Indonesia for supporting this work through Penelitian Dasar Perguruan Tinggi (PDUPT) Grant No. NKB-197/ UN2.RST/HKP.05.00/2020.

\section{References}

Adam KP. 1996. XII Jamesoniella autumnalis (Liverwort): culture and production of metabolites. In: Bajaj YPS (Eds.). Biotechnology in Agriculture and Forestry: Volume 43, Medicinal and Aromatic Plants XI. New York: Springer. pp. 213-222. DOI:10.1007/978-3662-08614-8

Awasthi DK. 2009. Cryptogams: Algae, Bryophyta and Pteridophyta. 2nd ed. Meerut: Krishna Prakashan Media.

Awasthi V, Pande N. 2015. In Vitro culture of an endangered and endemic Indian liverwort: Stephensoniella brevipedunculata Kashyap (Marchantiophyta). National Academy Science Letters 38:517-519. DOI:10.1007/s40009-015-0371-7

Ayele YZ, Tefera W. 2018. Low cost sterilization technique and in vitro initiation of vanilla (Vanilla planifolia Andr.) Journal of Agricultural Science and Food Research 9:1-6.

Beike AK et al. 2010. Technical notes: Axenic bryophyte in vitro cultivation. Journal of Endocytobiosis and Cell Research 20:102-108.

Chopra RN, Kumra PK. 1988. Biology of Bryophytes. New Delhi: Wiley Eastern Limited.

Chopra I, Roberts M. 2001. Tetracycline antibiotics: mode of action, applications, molecular biology, and epidemiology of bacterial resistance. Microbiology and Molecular Biology Reviews 65:232-260. DOI:10.1128/ MMBR.65.2.232-260.2001

Duckett JG et al. 2004. In vitro cultivation of bryophytes: a review of practicalities, problems, progress and promise. Journal of Bryology 26:3-20. DOI:10.1179/037366803235001742

Estrela C et al. 2002. Mechanism of action of sodium hypochlorite. Brazilian Dental Journal 13:113-117. DOI:10.1590/S0103-64402002000200007

Firoz AM et al. 2016. Studies on the effect of various sterilization procedure for in vitro seed germination and successful micropropagation of Cucumis sativus. International Journal Pure and Applied Bioscience 4:7581. DOI:10.18782/2320-7051.2226

George EF. 2008. Plant tissue culture procedure-background. In: George EF, Hall MA, Klerk GJD (Eds.). Plant Propagation by Tissue Culture: Volume 1, The Background. 3rd ed. Netherlands: Springer. pp. 1-28. DOI:10.1007/978-1-4020-5005-3

Gradstein SR et al. 1988. On the taxonomic significance of secondary metabolites in the Lejeuneaceae hepatica. Journal-Hattori Botanical Laboratory 64:159-168.

Hua L et al. 2008. Mechanisms of oxidative browning of wine. Food Chemistry 108:1-13. DOI:10.1016/j. foodchem.2007.10.065

Krishnan R, Murugan K. 2014. Establishment of in vitro and temporarily immersed cultures using rita ${ }^{\circledR}$ of Marchantia Linearis Lehm. and Lindenb. A liverwort. International Journal of Life Sciences Biotechnology and Pharma Research 3:59-68.
Krishnan R et al. 2014. Establishment of cell suspension culture in Marchantia linearis Lehm and Lindenb. for the optimum production of flavonoids. Biotechnology 4:49-56. DOI:10.1007/s13205-013-0123-7

Kritzinger EM et al. 1997. Elimination of external and internal contaminants in Rhizomes of Zantedeschia Aethiopica with commercial fungicides and antibiotics. In: Cassells AC (Eds.). Pathogen and Microbial Contamination Management in Micropropagation. Dordrecht: Kluwer Academic Publishers. pp. 161-167. DOI:10.1007/978-94-015-8951-2_19

Kumar S, Singh MP. 2009. Plant Tissue Culture. New Delhi: APH Publishing Corporation.

Kutschera U, Koopmann V. 2005. Growth in liverworts of the marchantiales is promoted by epiphytic Methylobacteria. Naturwissenschaften 92:347-349. DOI:10.1007/s00114-005-0640-2

Mng'omba SA et al. 2012. Chapter 12. Efficacy and utilization of fungicides and other antibiotics for aseptic plant cultures. In: Dhanasekaran D (Eds.). Fungicides for Plant and Animal Diseases. Croatia: InTech. pp. 245254. DOI:10.5772/27662

Nadir M. 2018. Teknik sterilisasi dan regenerasi in vitro eksplan cabang rumput gajah mini odot (Pennisetum purpureum CV. Mott). In: Nadir M (Eds.). Senarai Penelitian Regenerasi Sektor Pertanian: SDM, SocioAgroTechnoEcology. Yogyakarta: Deepublish. pp. 49-53.

Sabovljevic M et al. 2003. In vitro culture of mosses: Aloina aloides (K.F.Schultz) Kindb., Brachythecium velutinum (Hedw.) B.S. and G. Ceratodon purpureus (Hedw.) Brid., Eurhynchium praelongum (Hedw.) B.S. and G. and Grimmia pulvinata (Hedw.) Sm. Turkish Journal of Botany 27:441-446.

Sabovljevic A et al. 2009. Chapter 10: in vitro culture and secondary metabolite isolation in bryophytes. In: Jain SM, Saxena PK (Eds.). Methods in Molecular Biology, Protocols for In Vitro Cultures and Secondary Metabolite Analysis of Aromatic and Medicinal Plants: Volume 547. New York: Humana Press. pp. 117-127. DOI:10.1007/978-1-60327-287-2

Sabovljevic A et al. 2012. Axenically culturing the bryophytes: establishment and propagation of the pleurocarpous Moss Thamnobryum Alopecurum nieuwland ex gangulee (bryophyta, neckeraceae) in in vitro conditions. Pakistan Journal of Botany 44:339-344.

Siregar ES et al. 2014. Lejeuneaceae anak suku Ptychanthoideae di Hutan Sibayak Sumatra Utara. Floribunda 4:218237. DOI:10.32556/floribunda.v4i8.2014.118

Thiers BM. 1982. Branching in the Lejeuneaceae I: a comparison of branch development in Aphanolejeunea and Cololejeunea. The Bryologist 85:104-109. DOI:10.2307/3243149

Vujicic M et al. 2010. Axenically culturing the bryophytes: a case study of the liverwort Marchantia polymorpha L. ssp. ruderalis bischl. and boisselier (Marchantiophyta, Marchantiaceae). Kragujevac Journal of Science 32:7381.

Wang J et al. 2014. Phylogenetic position of trocholejeunea and a new infrageneric classification of Acrolejeunea (Lejeuneaceae, Marchantiophyta). Bryophyte Diversity and Evolution 36:31-44. DOI:10.11646/bde.36.1.3 